BENEDITO RODRIGUES DA SILVA NETO

(ORGANIZADOR)

\title{
PROJETOS INOVADORES E
}

PRODUÇÃO INTELECTUAL

NA MICROBIOLOCIA

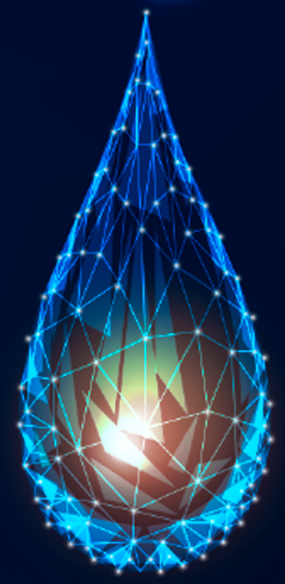

Q

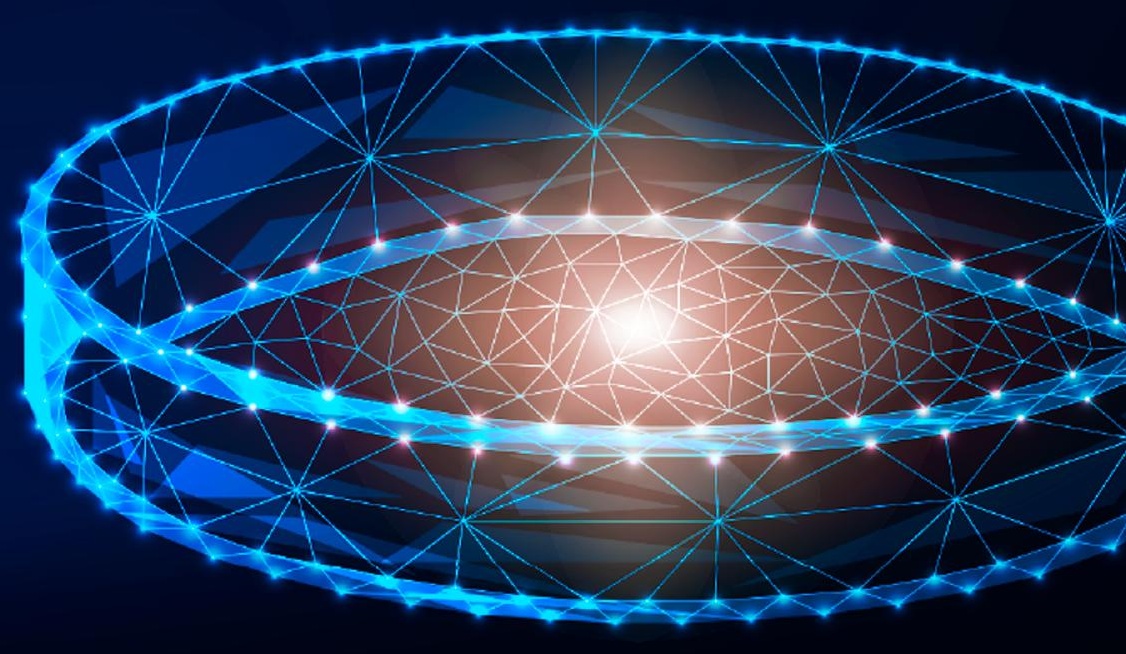

Ano 2020 
BENEDITO RODRIGUES DA SILVA NETO

(ORGANIZADOR)

\section{PROJETOS INOVADORES E}

PRODUÇÃO INTELECTUAL

NA MICROBIOLOGIA

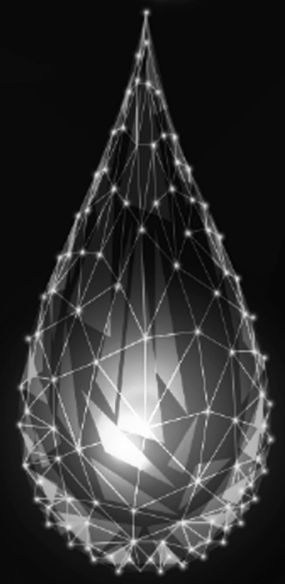

$\Delta$ tena

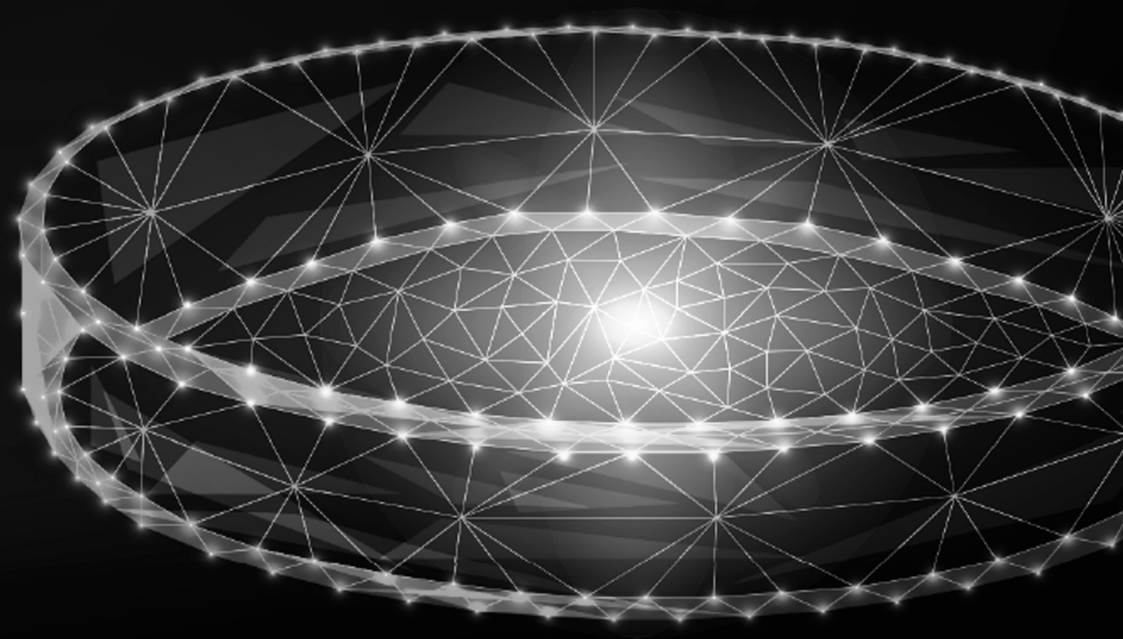

Ano 2020 


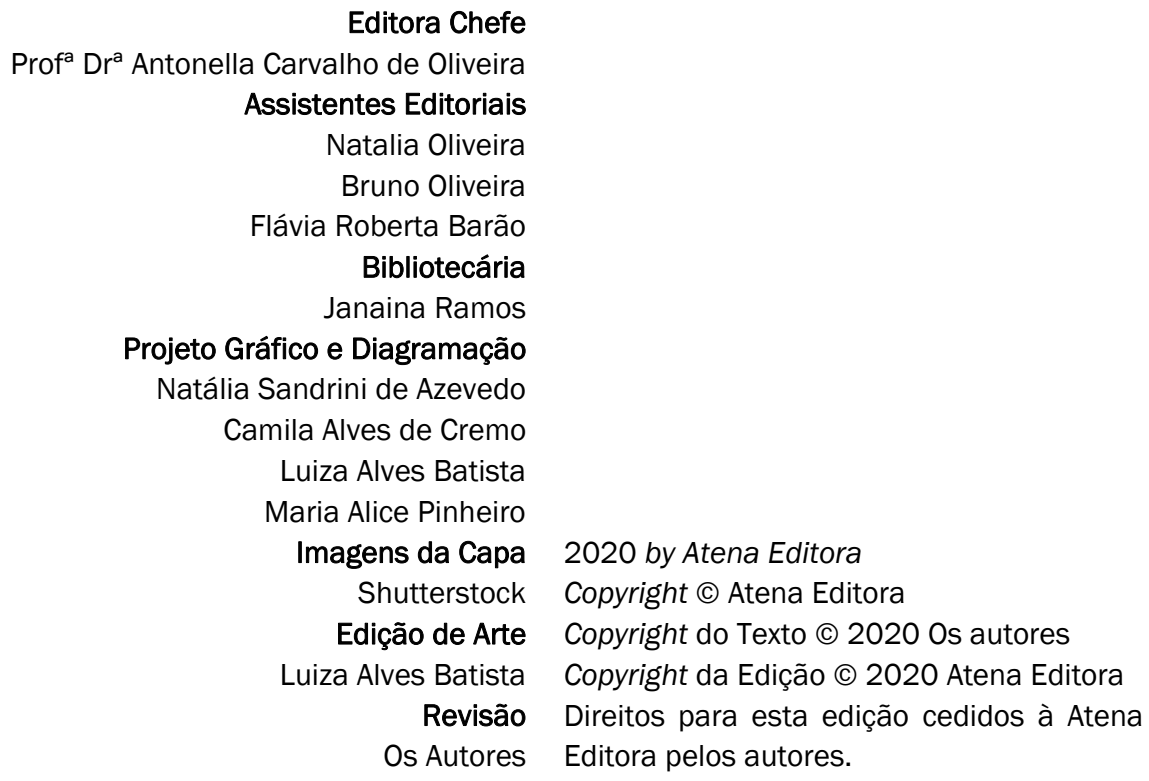

Todo o conteúdo deste livro está licenciado sob uma Licença de Atribuição Creative Commons. Atribuição-Não-ComercialNãoDerivativos 4.0 Internacional (CC BY-NC-ND 4.0).

O conteúdo dos artigos e seus dados em sua forma, correção e confiabilidade são de responsabilidade exclusiva dos autores, inclusive não representam necessariamente a posição oficial da Atena Editora. Permitido o download da obra e o compartilhamento desde que sejam atribuídos créditos aos autores, mas sem a possibilidade de alterá-la de nenhuma forma ou utilizá-la para fins comerciais.

Todos os manuscritos foram previamente submetidos à avaliação cega pelos pares, membros do Conselho Editorial desta Editora, tendo sido aprovados para a publicação.

A Atena Editora é comprometida em garantir a integridade editorial em todas as etapas do processo de publicação. Situações suspeitas de má conduta científica serão investigadas sob o mais alto padrão de rigor acadêmico e ético.

\section{Conselho Editorial}

Ciências Humanas e Sociais Aplicadas

Prof. Dr. Alexandre Jose Schumacher - Instituto Federal de Educação, Ciência e Tecnologia do Paraná

Prof. Dr. Américo Junior Nunes da Silva - Universidade do Estado da Bahia

Prof. Dr. Antonio Carlos Frasson - Universidade Tecnológica Federal do Paraná

Prof. Dr. Antonio Gasparetto Júnior - Instituto Federal do Sudeste de Minas Gerais

Prof. Dr. Antonio Isidro-Filho - Universidade de Brasília

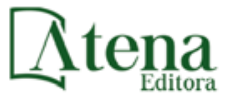

Ano 2020 
Prof. Dr. Carlos Antonio de Souza Moraes - Universidade Federal Fluminense

Prof $^{a}$ Dr $^{\text {a }}$ Cristina Gaio - Universidade de Lisboa

Prof. Dr. Daniel Richard Sant'Ana - Universidade de Brasília

Prof. Dr. Deyvison de Lima Oliveira - Universidade Federal de Rondônia

Prof ${ }^{a}$ Dr $^{\text {a }}$ Dilma Antunes Silva - Universidade Federal de São Paulo

Prof. Dr. Edvaldo Antunes de Farias - Universidade Estácio de Sá

Prof. Dr. Elson Ferreira Costa - Universidade do Estado do Pará

Prof. Dr. Eloi Martins Senhora - Universidade Federal de Roraima

Prof. Dr. Gustavo Henrique Cepolini Ferreira - Universidade Estadual de Montes Claros

Prof $^{a} \mathrm{Dr}^{\mathrm{a}}$ Ivone Goulart Lopes - Istituto Internazionele delle Figlie de Maria Ausiliatrice

Prof. Dr. Jadson Correia de Oliveira - Universidade Católica do Salvador

Prof. Dr. Julio Candido de Meirelles Junior - Universidade Federal Fluminense

Prof $^{a} \mathrm{Dr}^{\mathrm{a}}$ Lina Maria Gonçalves - Universidade Federal do Tocantins

Prof. Dr. Luis Ricardo Fernandes da Costa - Universidade Estadual de Montes Claros

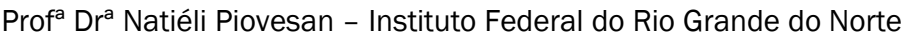

Prof. Dr. Marcelo Pereira da Silva - Pontifícia Universidade Católica de Campinas

Prof $^{a}$ Dr $^{a}$ Maria Luzia da Silva Santana - Universidade Federal de Mato Grosso do Sul

Prof $^{a}$ Dr $^{\text {a }}$ Paola Andressa Scortegagna - Universidade Estadual de Ponta Grossa

Prof $^{a}$ Dr $^{a}$ Rita de Cássia da Silva Oliveira - Universidade Estadual de Ponta Grossa

Prof. Dr. Rui Maia Diamantino - Universidade Salvador

Prof. Dr. Urandi João Rodrigues Junior - Universidade Federal do Oeste do Pará

Prof $^{a}$ Dr $^{a}$ Vanessa Bordin Viera - Universidade Federal de Campina Grande

Prof. Dr. William Cleber Domingues Silva - Universidade Federal Rural do Rio de Janeiro

Prof. Dr. Willian Douglas Guilherme - Universidade Federal do Tocantins

\section{Ciências Agrárias e Multidisciplinar}

Prof. Dr. Alexandre Igor Azevedo Pereira - Instituto Federal Goiano

Prof $^{\mathrm{a}} \mathrm{Dr}^{\mathrm{a}}$ Carla Cristina Bauermann Brasil - Universidade Federal de Santa Maria

Prof. Dr. Antonio Pasqualetto - Pontifícia Universidade Católica de Goiás

Prof. Dr. Cleberton Correia Santos - Universidade Federal da Grande Dourados

Prof $^{a}$ Dr $^{a}$ Daiane Garabeli Trojan - Universidade Norte do Paraná

Prof ${ }^{a}$ Dr $^{a}$ Diocléa Almeida Seabra Silva - Universidade Federal Rural da Amazônia

Prof. Dr. Écio Souza Diniz - Universidade Federal de Viçosa

Prof. Dr. Fábio Steiner - Universidade Estadual de Mato Grosso do Sul

Prof. Dr. Fágner Cavalcante Patrocínio dos Santos - Universidade Federal do Ceará

Prof ${ }^{a}$ Dr $^{a}$ Girlene Santos de Souza - Universidade Federal do Recôncavo da Bahia

Prof. Dr. Jael Soares Batista - Universidade Federal Rural do Semi-Árido

Prof. Dr. Júlio César Ribeiro - Universidade Federal Rural do Rio de Janeiro

Prof $^{a}$ Dr $^{a}$ Lina Raquel Santos Araújo - Universidade Estadual do Ceará

Prof. Dr. Pedro Manuel Villa - Universidade Federal de Viçosa

Prof $^{a}$ Dr $^{a}$ Raissa Rachel Salustriano da Silva Matos - Universidade Federal do Maranhão

Prof. Dr. Ronilson Freitas de Souza - Universidade do Estado do Pará

Prof $^{\mathrm{a}} \mathrm{Dr}^{\mathrm{a}}$ Talita de Santos Matos - Universidade Federal Rural do Rio de Janeiro

Prof. Dr. Tiago da Silva Teófilo - Universidade Federal Rural do Semi-Árido

Prof. Dr. Valdemar Antonio Paffaro Junior - Universidade Federal de Alfenas

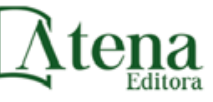

Ano 2020 


\section{Ciências Biológicas e da Saúde}

Prof. Dr. André Ribeiro da Silva - Universidade de Brasília

Prof $^{\mathrm{a}} \mathrm{Dr}^{\mathrm{a}}$ Anelise Levay Murari - Universidade Federal de Pelotas

Prof. Dr. Benedito Rodrigues da Silva Neto - Universidade Federal de Goiás

Prof $^{a}$ Dr $^{a}$ Débora Luana Ribeiro Pessoa - Universidade Federal do Maranhão

Prof. Dr. Douglas Siqueira de Almeida Chaves -Universidade Federal Rural do Rio de Janeiro

Prof. Dr. Edson da Silva - Universidade Federal dos Vales do Jequitinhonha e Mucuri

Prof $^{\mathrm{a}} \mathrm{Dr}^{\mathrm{a}}$ Eleuza Rodrigues Machado - Faculdade Anhanguera de Brasília

Prof $^{a}$ Dr $^{\mathrm{a}}$ Elane Schwinden Prudêncio - Universidade Federal de Santa Catarina

Prof $^{\mathrm{a}}$ Dr $^{\mathrm{a}}$ Eysler Gonçalves Maia Brasil - Universidade da Integração Internacional da Lusofonia

Afro-Brasileira

Prof. Dr. Ferlando Lima Santos - Universidade Federal do Recôncavo da Bahia

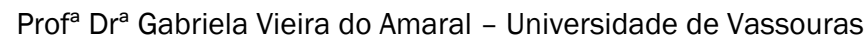

Prof. Dr. Gianfábio Pimentel Franco - Universidade Federal de Santa Maria

Prof. Dr. Helio Franklin Rodrigues de Almeida - Universidade Federal de Rondônia

Prof $^{a}$ Dr $^{\mathrm{a}}$ lara Lúcia Tescarollo - Universidade São Francisco

Prof. Dr. Igor Luiz Vieira de Lima Santos - Universidade Federal de Campina Grande

Prof. Dr. Jefferson Thiago Souza - Universidade Estadual do Ceará

Prof. Dr. Jesus Rodrigues Lemos - Universidade Federal do Piauí

Prof. Dr. Jônatas de França Barros - Universidade Federal do Rio Grande do Norte

Prof. Dr. José Max Barbosa de Oliveira Junior - Universidade Federal do Oeste do Pará

Prof. Dr. Luís Paulo Souza e Souza - Universidade Federal do Amazonas

Prof $^{\mathrm{a}} \mathrm{Dr}^{\mathrm{a}}$ Magnólia de Araújo Campos - Universidade Federal de Campina Grande

Prof. Dr. Marcus Fernando da Silva Praxedes - Universidade Federal do Recôncavo da Bahia

Prof $^{\mathrm{a}} \mathrm{Dr}^{\mathrm{a}}$ Maria Tatiane Gonçalves Sá - Universidade do Estado do Pará

Prof $^{a}$ Dr $^{\text {a }}$ Mylena Andréa Oliveira Torres - Universidade Ceuma

Prof $^{\mathrm{a}}$ Dr $^{\mathrm{a}}$ Natiéli Piovesan - Instituto Federacl do Rio Grande do Norte

Prof. Dr. Paulo Inada - Universidade Estadual de Maringá

Prof. Dr. Rafael Henrique Silva - Hospital Universitário da Universidade Federal da Grande Dourados

Prof $^{a}$ Dr $^{\mathrm{a}}$ Regiane Luz Carvalho - Centro Universitário das Faculdades Associadas de Ensino

Prof $^{a}$ Dr $^{a}$ Renata Mendes de Freitas - Universidade Federal de Juiz de Fora

Prof $^{a}$ Dr $^{a}$ Vanessa Lima Gonçalves - Universidade Estadual de Ponta Grossa

Prof $^{\mathrm{a}} \mathrm{Dr}^{\mathrm{a}}$ Vanessa Bordin Viera - Universidade Federal de Campina Grande

\section{Ciências Exatas e da Terra e Engenharias}

Prof. Dr. Adélio Alcino Sampaio Castro Machado - Universidade do Porto

Prof. Dr. Carlos Eduardo Sanches de Andrade - Universidade Federal de Goiás

Prof $^{\mathrm{a}} \mathrm{Dr}^{\mathrm{a}}$ Carmen Lúcia Voigt - Universidade Norte do Paraná

Prof. Dr. Douglas Gonçalves da Silva - Universidade Estadual do Sudoeste da Bahia

Prof. Dr. Eloi Rufato Junior - Universidade Tecnológica Federal do Paraná

Prof $^{a}$ Dr $^{a}$ Érica de Melo Azevedo - Instituto Federal do Rio de Janeiro

Prof. Dr. Fabrício Menezes Ramos - Instituto Federal do Pará

Prof $^{a}$ Dra. Jéssica Verger Nardeli - Universidade Estadual Paulista Júlio de Mesquita Filho

Prof. Dr. Juliano Carlo Rufino de Freitas - Universidade Federal de Campina Grande

Prof $^{\mathrm{a}} \mathrm{Dr}^{\mathrm{a}}$ Luciana do Nascimento Mendes - Instituto Federal de Educação, Ciência e Tecnologia do Rio Grande do Norte

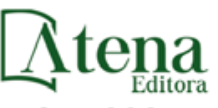


Prof. Dr. Marcelo Marques - Universidade Estadual de Maringá

Prof $^{a} \operatorname{Dr}^{\mathrm{a}}$ Neiva Maria de Almeida - Universidade Federal da Paraíba

Prof $^{a}$ Dr $^{a}$ Natiéli Piovesan - Instituto Federal do Rio Grande do Norte

Prof ${ }^{a}$ Dr $^{\text {a }}$ Priscila Tessmer Scaglioni - Universidade Federal de Pelotas

Prof. Dr. Takeshy Tachizawa - Faculdade de Campo Limpo Paulista

\section{Linguística, Letras e Artes}

Prof $^{a}$ Dr $^{a}$ Adriana Demite Stephani - Universidade Federal do Tocantins

Prof $^{a}$ Dr $^{a}$ Angeli Rose do Nascimento - Universidade Federal do Estado do Rio de Janeiro

Prof $^{a}$ Dr $^{\text {a }}$ Carolina Fernandes da Silva Mandaji - Universidade Tecnológica Federal do Paraná

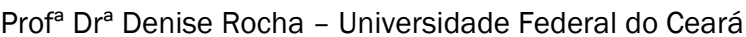

Prof. Dr. Fabiano Tadeu Grazioli - Universidade Regional Integrada do Alto Uruguai e das Missões

Prof. Dr. Gilmei Fleck - Universidade Estadual do Oeste do Paraná

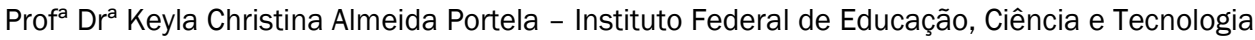
do Paraná

Prof $^{a}$ Dra $^{a}$ Miranilde Oliveira Neves - Instituto de Educação, Ciência e Tecnologia do Pará

Prof $^{a}$ Dr $^{\text {a }}$ Sandra Regina Gardacho Pietrobon - Universidade Estadual do Centro-Oeste

Prof $^{a}$ Dr $^{\text {a }}$ Sheila Marta Carregosa Rocha - Universidade do Estado da Bahia

\section{Conselho Técnico Científico}

Prof. Me. Abrãao Carvalho Nogueira - Universidade Federal do Espírito Santo

Prof. Me. Adalberto Zorzo - Centro Estadual de Educação Tecnológica Paula Souza

Prof. Me. Adalto Moreira Braz - Universidade Federal de Goiás

Prof. Dr. Adaylson Wagner Sousa de Vasconcelos - Ordem dos Advogados do Brasil/Seccional Paraíba

Prof. Dr. Adilson Tadeu Basquerote Silva - Universidade para o Desenvolvimento do Alto Vale do Itajaí

Prof. Me. Alexsandro Teixeira Ribeiro - Centro Universitário Internacional

Prof. Me. André Flávio Gonçalves Silva - Universidade Federal do Maranhão

Prof ${ }^{a}$ Ma. Andréa Cristina Marques de Araújo - Universidade Fernando Pessoa

Prof $^{a}$ Dr $^{\text {a }}$ Andreza Lopes - Instituto de Pesquisa e Desenvolvimento Acadêmico

Prof $^{a}$ Dr $^{a}$ Andrezza Miguel da Silva - Faculdade da Amazônia

Prof ${ }^{a}$ Ma. Anelisa Mota Gregoleti - Universidade Estadual de Maringá

Prof ${ }^{a}$ Ma. Anne Karynne da Silva Barbosa - Universidade Federal do Maranhão

Prof. Dr. Antonio Hot Pereira de Faria - Polícia Militar de Minas Gerais

Prof. Me. Armando Dias Duarte - Universidade Federal de Pernambuco

Prof $^{a}$ Ma. Bianca Camargo Martins - UniCesumar

Prof $^{a}$ Ma. Carolina Shimomura Nanya - Universidade Federal de São Carlos

Prof. Me. Carlos Antônio dos Santos - Universidade Federal Rural do Rio de Janeiro

Prof. Ma. Cláudia de Araújo Marques - Faculdade de Música do Espírito Santo

Prof $^{a}$ Dr $^{a}$ Cláudia Taís Siqueira Cagliari - Centro Universitário Dinâmica das Cataratas

Prof. Me. Clécio Danilo Dias da Silva - Universidade Federal do Rio Grande do Norte

Prof. Me. Daniel da Silva Miranda - Universidade Federal do Pará

Prof $^{a}$ Ma. Daniela da Silva Rodrigues - Universidade de Brasília

Prof $^{\mathrm{a}}$ Ma. Daniela Remião de Macedo - Universidade de Lisboa

Prof $^{a}$ Ma. Dayane de Melo Barros - Universidade Federal de Pernambuco

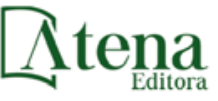

Ano 2020 
Prof. Me. Douglas Santos Mezacas - Universidade Estadual de Goiás

Prof. Me. Edevaldo de Castro Monteiro - Embrapa Agrobiologia

Prof. Me. Eduardo Gomes de Oliveira - Faculdades Unificadas Doctum de Cataguases

Prof. Me. Eduardo Henrique Ferreira - Faculdade Pitágoras de Londrina

Prof. Dr. Edwaldo Costa - Marinha do Brasil

Prof. Me. Eliel Constantino da Silva - Universidade Estadual Paulista Júlio de Mesquita

Prof. Me. Ernane Rosa Martins - Instituto Federal de Educação, Ciência e Tecnologia de Goiás

Prof. Me. Euvaldo de Sousa Costa Junior - Prefeitura Municipal de São João do Piauí

Prof $^{a}$ Ma. Fabiana Coelho Couto Rocha Corrêa - Centro Universitário Estácio Juiz de Fora

Prof. Me. Felipe da Costa Negrão - Universidade Federal do Amazonas

Prof $^{a}$ Dr $^{a}$ Germana Ponce de Leon Ramírez - Centro Universitário Adventista de São Paulo

Prof. Me. Gevair Campos - Instituto Mineiro de Agropecuária

Prof. Me. Givanildo de Oliveira Santos - Secretaria da Educação de Goiás

Prof. Dr. Guilherme Renato Gomes - Universidade Norte do ParanáProf. Me. Gustavo Krahl Universidade do Oeste de Santa Catarina

Prof. Me. Helton Rangel Coutinho Junior - Tribunal de Justiça do Estado do Rio de Janeiro

Prof $^{\mathrm{a}} \mathrm{Ma}$. Isabelle Cerqueira Sousa - Universidade de Fortaleza

Prof $^{a}$ Ma. Jaqueline Oliveira Rezende - Universidade Federal de Uberlândia

Prof. Me. Javier Antonio Albornoz - University of Miami and Miami Dade College

Prof. Me. Jhonatan da Silva Lima - Universidade Federal do Pará

Prof. Dr. José Carlos da Silva Mendes - Instituto de Psicologia Cognitiva, Desenvolvimento Humano e Social

Prof. Me. Jose Elyton Batista dos Santos - Universidade Federal de Sergipe

Prof. Me. José Luiz Leonardo de Araujo Pimenta - Instituto Nacional de Investigación Agropecuaria Uruguay

Prof. Me. José Messias Ribeiro Júnior - Instituto Federal de Educação Tecnológica de Pernambuco

Prof $^{\mathrm{a}} \mathrm{Dr}^{\mathrm{a}}$ Juliana Santana de Curcio - Universidade Federal de Goiás

Prof ${ }^{a}$ Ma. Juliana Thaisa Rodrigues Pacheco - Universidade Estadual de Ponta Grossa

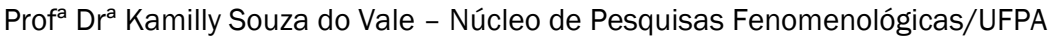

Prof. Dr. Kárpio Márcio de Siqueira - Universidade do Estado da Bahia

Prof $^{a}$ Dr $^{a}$ Karina de Araújo Dias - Prefeitura Municipal de Florianópolis

Prof. Dr. Lázaro Castro Silva Nascimento - Laboratório de Fenomenologia \& Subjetividade/UFPR

Prof. Me. Leonardo Tullio - Universidade Estadual de Ponta Grossa

Prof $^{a}$ Ma. Lilian Coelho de Freitas - Instituto Federal do Pará

Prof ${ }^{a}$ Ma. Liliani Aparecida Sereno Fontes de Medeiros - Consórcio CEDERJ

Prof $^{a}$ Dr $^{\mathrm{a}}$ Lívia do Carmo Silva - Universidade Federal de Goiás

Prof. Dr. Lucio Marques Vieira Souza - Secretaria de Estado da Educação, do Esporte e da Cultura de Sergipe

Prof. Me. Luis Henrique Almeida Castro - Universidade Federal da Grande Dourados

Prof. Dr. Luan Vinicius Bernardelli - Universidade Estadual do Paraná

Prof. Dr. Michel da Costa - Universidade Metropolitana de Santos

Prof. Dr. Marcelo Máximo Purificação - Fundação Integrada Municipal de Ensino Superior

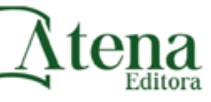

Ano 2020 
Prof. Me. Marcos Aurelio Alves e Silva - Instituto Federal de Educação, Ciência e Tecnologia de São Paulo

Prof ${ }^{a}$ Ma. Maria Elanny Damasceno Silva - Universidade Federal do Ceará

Prof ${ }^{a}$ Ma. Marileila Marques Toledo - Universidade Federal dos Vales do Jequitinhonha e Mucuri

Prof. Me. Ricardo Sérgio da Silva - Universidade Federal de Pernambuco

Prof ${ }^{a}$ Ma. Renata Luciane Polsaque Young Blood - UniSecal

Prof. Me. Robson Lucas Soares da Silva - Universidade Federal da Paraíba

Prof. Me. Sebastião André Barbosa Junior - Universidade Federal Rural de Pernambuco

Prof $^{a}$ Ma. Silene Ribeiro Miranda Barbosa - Consultoria Brasileira de Ensino, Pesquisa e Extensão

Prof $^{a}$ Ma. Solange Aparecida de Souza Monteiro - Instituto Federal de São Paulo

Prof. Me. Tallys Newton Fernandes de Matos - Faculdade Regional Jaguaribana

Prof $^{a}$ Ma. Thatianny Jasmine Castro Martins de Carvalho - Universidade Federal do Piauí

Prof. Me. Tiago Silvio Dedoné - Colégio ECEL Positivo

Prof. Dr. Welleson Feitosa Gazel - Universidade Paulista 
Editora Chefe: Prof $^{\mathrm{a}} \mathrm{Dr}^{\mathrm{a}}$ Antonella Carvalho de Oliveira

Bibliotecária: Janaina Ramos

Diagramação: Maria Alice Pinheiro

Correção: Mariane Aparecida Freitas

Edição de Arte: Luiza Alves Batista

Revisão: Os Autores

Organizador: Benedito Rodrigues da Silva Neto

Dados Internacionais de Catalogação na Publicação (CIP)

P964 Projetos inovadores e produção intelectual na microbiologia / Organizador Benedito Rodrigues da Silva Neto. Ponta Grossa - PR: Atena, 2020.

Formato: PDF

Requisitos de sistema: Adobe Acrobat Reader Modo de acesso: World Wide Web

Inclui bibliografia

ISBN 978-65-5706-574-7

DOI 10.22533/at.ed.747201711

1. Microbiologia. 2. Projetos. 3. Produção. I. Silva Neto, Benedito Rodrigues da (Organizador). II. Título.

CDD 579

Elaborado por Bibliotecária Janaina Ramos - CRB-8/9166

Atena Editora

Ponta Grossa - Paraná - Brasil Telefone: +55 (42) 3323-5493 www.atenaeditora.com.br contato@atenaeditora.com.br 


\section{DECLARAÇÃO DOS AUTORES}

Os autores desta obra: 1. Atestam não possuir qualquer interesse comercial que constitua um conflito de interesses em relação ao artigo científico publicado; 2. Declaram que participaram ativamente da construção dos respectivos manuscritos, preferencialmente na: a) Concepção do estudo, e/ou aquisição de dados, e/ou análise e interpretação de dados; b) Elaboração do artigo ou revisão com vistas a tornar o material intelectualmente relevante; c) Aprovação final do manuscrito para submissão.; 3. Certificam que os artigos científicos publicados estão completamente isentos de dados e/ou resultados fraudulentos. 


\section{APRESENTAÇÃO}

A microbiologia tem sido um assunto recorrente nos últimos anos, desde os corredores universitários aos locais informais, as conversas vão desde as bactérias multirresistentes, passando por novas espécies de fungos descobertos até chegar no atual momento de pandemia viral que marcará na história o ano de 2020. Esse campo de estudo amplo inclui o estudo dos seres vivos microscópicos nos seus mais vaiados aspectos como morfologia, estrutura, fisiologia, reprodução, genética, taxonomia, interação com outros organismos e com o ambiente além de aplicações biotecnológicas.

Como ciência, a microbiologia iniciou a cerca de duzentos anos atrás, e tem passado por constantes avanços graças a descobertas e inovações tecnológicas. Sabemos que os microrganismos são encontrados em praticamente todos os lugares, e a falta de conhecimento que havia antes da invenção do microscópio hoje não é mais um problema no estudo, principalmente das enfermidades relacionadas aos agentes como bactérias, vírus, fungos e protozoários.

A grande importância dessa temática se reflete no material de qualidade já publicado na Atena Editora e mais uma vez recebe os nossos holofotes com o tema "Projetos Inovadores e Produção Intelectual na Microbiologia" contendo trabalhos e pesquisas desenvolvidas em diversos institutos do território nacional contendo análises de processos biológicos embasados em células microbianas ou estudos científicos na fundamentação de atividades microbianas com capacidade de interferir nos processos de saúde/doença.

Temas ligados à inovação e tecnologia microbiana são, deste modo, discutidos aqui com a proposta de fundamentar o conhecimento de acadêmicos, mestres e todos aqueles que de alguma forma se interessam pela saúde em seus aspectos microbiológicos. Deste modo, propomos aqui uma teoria bem fundamentada nos resultados práticos obtidos em diferentes campos da microbiologia, abrindo perspectivas futuras para os demais pesquisadores de outras subáreas da microbiologia.

Desejamos a todos uma excelente leitura! 


\section{SUMÁRIO}

CAPÍTULO 1

AVALIAÇÃO DA QUALIDADE MICROBIOLOGICA DOS CANAIS DO MUNICÍPIO DE SÃO VICENTE

José Augusto de Souza

Roberta Alves Merguizo Chinellato

Mirella Massonetto Basilio

Vanessa da Costa Andrade

Ana Julia Fernandes Cardoso de Oliveira

DOI 10.22533/at.ed.7472017111

CAPÍTULO 2

AVALIAÇÃO DE CULTURA E TESTE DE SENSIBILIDADE DA TUBERCULOSE PULMONAR NO BRASIL NO ANO DE 2016

Vinicius Mateus Salvatori Cheute

Fabiana de Oliveira Solla Sobral

Renan Fava Marson

Wesley Pimenta Cândido

DOI 10.22533/at.ed.7472017112

CAPÍTULO 3

AVALIAÇÃO DE CULTURAS DE ESCARRO PARA O DIAGNÓSTICO DE TUBERCULOSE EM 2017

Iaci Gama Fortes

Lysia Alves Oliva

Bianca Melo Amorim

Karline Drieli Wottrich

DOI 10.22533/at.ed.7472017113

CAPÍTULO 4

AVALIAÇÃO IN VITRO DO POTENCIAL ANTIMICROBIANO DE EXTRATOS FOLIARES DE GALLESIA INTEGRIFOLIA (SPRENG) HARMS (PHYTOLACCACEAE)

Julyanna Oliveira Castro

Marcelo Schramm Mielke

Aline Oliveira da Conceição

DOI 10.22533/at.ed.7472017114

CAPÍTULO 5 38

CARACTERIZAÇÃO EPIDEMIOLÓGICA DOS CASOS DE DENGUE NO MUNICÍPIO DE SOBRAL-CEARA, ENTRE O PERÍODO DE 2014 A 2017

Manoel Vieira do Nascimento Junior

José Jackson do Nascimento Costa

Maria Amélia Araújo Soares Costa

DOI 10.22533/at.ed.7472017115 
CONTAMINATION ASSESSMENT OF BIVALVE MOLLUSK INTENDED FOR HUMAN CONSUMPTION PRODUCED IN COASTAL WATERS OF NORTHERN BRAZIL

Daniela Cristiane da Cruz Rocha

Aline Holanda Sousa

Debora de Castro Costa

Karina Lúcia Silva da Silva

Anderson Nonato do Rosario Marinho

DOI 10.22533/at.ed.7472017116

CAPÍTULO 7

FATORES RELACIONADOS AS INFECÇÕES HOSPITALARES POR BACTÉRIAS: UMA REVISÃO NARRATIVA

Érica Cristina Soares e Silva

Antônio Rosa de Sousa Neto

Daniella Farias Almeida

Mayara Macêdo Melo

Marly Marques Rêgo Neta

Rosângela Nunes Almeida

Inara Viviane de Oliveira Sena

Daniela Reis Joaquim Freitas

DOI 10.22533/at.ed.7472017117

CAPÍTULO 8

BIOPROSPECÇÂO DE FUNGOS FILAMENTOSOS VISANDO ESTUDOS DE AMILASES E PECTINASES COM APLICAÇÃO EM PROCESSOS INDUSTRIAIS

Daniel Borba Zanelatto

Mariana Cereia

Tássio Brito de Oliveira

Maria de Lourdes Teixeira de Moraes Polizeli

DOI 10.22533/at.ed.7472017118

CAPÍTULO 9

PROJETOS INOVADORES E PRODUÇÃO INTELECTUAL NA MICROBIOLOGIA INNOVATIVE PROJECTS AND INTELLECTUAL PRODUCTION IN MICROBIOLOGY

Patrícia Regina Kitaka

Marta Cristina Teixeira Duarte

Valéria Maia de Oliveira

Maria da Graça S. Andrietta

DOI 10.22533/at.ed.7472017119

CAPÍTULO 10

INVESTIGAÇÃO DE FUNGOS PRODUTORES DE ENZIMAS DE INTERESSE BIOTECNOLÓGICO

Layne Even Borges de Souza

Leidiana Pinto da Costa

Rafael Cardoso Bastos

Thayana Cruz de Souza

DOI 10.22533/at.ed.74720171110 
OTIMIZAÇÃO DA PRODUÇÃO DE QUITINASE PELO FUNGO ENDOFÍTICO CURVULARIA SP. URM 6861

Aline Gleyce Julião Bomfim

Edson Flávio Teixeira da Silva

Wellington Leal dos Santos

Maria Emília Brito da Silva

Cristina Maria de Souza-Motta

Keila Aparecida Moreira

DOI 10.22533/at.ed.74720171111

CAPÍTULO 12

PARTIÇÃO DE PROTEASES FIBRINOLÍTICAS PRODUZIDAS POR ASPERGILLUS TAMARII KITA UCP 1279 ATRAVÉS DO SISTEMA DE DUAS FASES AQUOSAS PEGFOSFATO

Viviane do Nascimento e Silva Alencar

Maria Clara do Nascimento

Julyanne Victória dos Santos Ferreira

Márcia Nieves Carneiro da Cunha

Juanize Matias da Silva Batista

Thiago Pajeú Nascimento

Romero Marcos Pedrosa Brandão Costa

Ana Lucia Figueiredo Porto

Ana Cristina Lima Leite

DOI 10.22533/at.ed.74720171112

CAPÍTULO 13

PRODUÇÃO DE PROTEASES POR ASPERGILLUS TAMARII KITA UCP 1279 ISOLADO DA CAATINGA UTILIZANDO RESÍDUOS AGROINDUSTRIAIS

Julyanne Victória dos Santos Ferreira

Kethylen Bárbara Barbosa Cardoso

Amanda Lucena dos Santos

Viviane do Nascimento e Silva Alencar

Maria Clara do Nascimento

Marcia Nieves Carneiro da Cunha

Juanize Matias da Silva Batista

Romero Pedrosa Brandão Costa

Thiago Pajeú Nascimento

Ana Cristina Lima Leite

Ana Lúcia Figueiredo Porto

DOI 10.22533/at.ed.74720171113

CAPÍTULO 14

PRODUCTION OF YEAST BIOMASS AND CELL WALL TO OBTAIN $\beta$ GLUCANS FOR A BIOTECHNOLOGICAL PURPOSE

Carina Maricel Pereyra

DOI 10.22533/at.ed.74720171114 
REMOÇÃO DO ÁCIDO ACETILSALICÍLICO EMPREGANDO BIOFILME MICROBIANO DESENVOLVIDO NATURALMENTE EM AREIA DE FILTROS DE ESTAÇÕES DE TRATAMENTO DE ÁGUA - UM ESTUDO COMPARATIVO COM DIFERENTES SUPORTES

Lúcia Allebrandt da Silva Ries

Karla Joseane Perez

Fernanda Cortez Lopes

Paula Silva Pereira

DOI 10.22533/at.ed.74720171115

CAPÍTULO 16 176

TUBERCULOSE: ASPECTOS DA INFECÇÃO CAUSADA POR MYCOBACTERIUM TUBERCULOSIS NA POPULAÇÃO DE SOBRAL, NO ESTADO DO CEARÁ NO PERÍODO DE 2012-2016

Sabrina Fuziger Inácio Brandão

Anderson Braga Rodrigues

Karla Karoline Frota da Silva

Isana Mara Aragão Frota

DOI 10.22533/at.ed.74720171116

SOBRE O ORGANIZADOR

ÍNDICE REMISSIVO 


\section{PRODUCTION OF YEAST BIOMASS AND CELL WALL TO OBTAIN B GLUCANS FOR A BIOTECHNOLOGICAL PURPOSE}

Data de aceite: 01/10/2020

\section{Carina Maricel Pereyra}

Universidad Nacional de Río Cuarto, Facultad de Ciencias Exactas, Físico Químicas y Naturales, Departamento de Microbiología e Inmunología. Instituto para el Desarrollo Agroindustrial y de la Salud. Consejo Nacional de Investigaciones Científicas y Técnicas (CONICET). Río Cuarto, Córdoba, Argentina.

ABSTRACT: Considering that the composition of the yeast cell wall can vary with respect to different growth conditions, the objective of this study was to determine the influence of additives (EDTA, $\mathrm{SDS}, \mathrm{NaCl}$ ) on the production of yeast biomass, the percentage of cell wall and its composition, in order to obtain $\beta$-glucan. The extraction of the cell wall was carried out by an alkaline extraction technique and the study of the composition was carried out using infrared (IR) spectroscopy. The production of biomass and cell wall was variable, depending on the strain and the treatments studied. The IR spectra of each cell wall showed three characteristic regions of the wall (polysaccharides, proteins and lipids). In addition, it was possible to determine the chemical groups corresponding to $\beta$-glucan and amides I and II corresponding to chitin. The glucans content, and the $\beta$-glucan/chitin ratio in particular, varied with the yeast strain and with the additive studied. Future studies must be performed to extract the $\beta$-glucans and determine their concentration in each cell wall. The optimization of the production of cell wall and its components from yeast strains will allow its application in obtaining $\beta$-glucans for the food, pharmacological and cosmetic industries.

KEYWORDS: Additives, $\beta$-glucans, Cell Wall, Yeast.

\section{PRODUÇÃO DE BIOMASSA DE LEVEDURA E PAREDE CELULAR PARA OBTER B GLUCANOS PARA UM PROPÓSITO BIOTECNOLÓGICO}

RESUMO: Considerando que a composição da parede celular da levedura pode variar em função de diferentes condições de crescimento, o objetivo deste trabalho foi determinar a influência dos aditivos (EDTA, SDS, $\mathrm{NaCl}$ ) na produção de biomassa de levedura, a porcentagem de parede celular e sua composição, a fim de obter $\beta$-glucano. A extração da parede celular foi realizada pela técnica de extração alcalina e o estudo da composição por espectroscopia de infravermelho (IV). A produção de biomassa e parede celular foi variável, dependendo da linhagem e dos tratamentos estudados. Os espectros de IV de cada parede celular mostraram três regiões características da parede (polissacarídeos, proteínas e lipídeos). Além disso, foi possível determinar os grupos químicos correspondentes à $\beta$-glucano e as amidas I e II correspondentes à quitina. $\mathrm{O}$ teor de glucanos, e a razão $\beta$-glucano/quitina em particular, variaram com a cepa de levedura e com o aditivo estudado. Estudos futuros devem ser realizados para extrair os $\beta$-glucanos e determinar sua concentração em cada parede celular. A otimização da produção 
da parede celular e seus componentes a partir de cepas de leveduras permitirá sua aplicação na obtenção de $\beta$-glucanos para a indústria alimentícia, farmacológica e cosmética.

PALAVRAS - CHAVE: Aditivos, $\beta$-glucanos, Parede Celular, Levedura.

\section{I INTRODUCTION}

Yeasts are unicellular fungi that can be found in a variety of environment, approximately 900 species of yeast have been described, although the species studied in depth to be used in biotechnology are scarce. Among the most important yeast species, Saccharomyces cerevisiae is stands, which is the yeast most used in industrial processes. In recent years, other so-called non-conventional yeast species have become increasingly relevant due to their positive contribution to both food and beverage fermentation. Some of these yeast genera include Pichia, Metschnikowia, Kluyveromyces and Issatchenkia that participate in cider and wine fermentations, dairy products, bread production, sausages and various vegetable fermentations (Romano et al., 2006).

\section{I YEAST BIOTECHNOLOGY}

Biotechnology is any technological application that uses biological systems and living organisms or derivatives to make or modification of products and processes for specific uses. The biotechnological bases are the engineering, physics, chemistry, biology, human and veterinary medicine; and the field of this science has a great impact on pharmacy, medicine, food science, solid, liquid, gaseous waste treatment and agriculture (OECD, 2005).

Traditional yeast biotechnology has been carried out since the beginning of human history through the baking of bread, the preparation of alcoholic beverages and the cultivation of food or the raising of domestic animals. Saccharomyces cerevisiae has been described as humanity's most domesticated organism and is still the most exploited yeast species in the industry today. But recent developments in molecular biology have given biotechnology new meaning, new prominence, and new potential. (https://www.thebeertimes.com/ saccharomyces-cerevisiae-y-las-claves-para-el-estudio-de-las-ciencias-de -life/).

Yeasts are the leading producer of biotech products worldwide, exceeding the production, capacity and economic income of any other group of industrial microorganisms. The global annual production of $S$. cerevisiae is over 1 million tons (Zymanczyk- Duda et al., 2017). Of all the yeast species studied, only a dozen is used on an industrial scale. On the other hand, around 70 to 80 laboratory scale species have been shown to have potential value in biotechnology (Deak, 2009; Kurtzman et al., 2011). 


\begin{tabular}{c|c}
\hline \multicolumn{2}{c}{ MAIN SPECIES OF BIOTECHNOLOGICAL IMPORTANCE } \\
\hline Saccharomyces cerevisiae & Scheffersomyces stipitis \\
\hline Schizosaccharomyces pombe & Picchia spp. \\
\hline Kluyveromyces lactis & Rhodotorula spp. \\
\hline Kluyveromyces marxianus & Rhodosporidium spp. \\
\hline Schwanniomyces occidentalis & Yarrowia lipolytica \\
\hline Lipomyces spp. & Candida spp. \\
\hline Saccharomycopsis spp. & Trichosporon spp. \\
\hline Debaromyces hansenii & Blastobotryss adeninivornas \\
\hline Ogataea polymorpha & Xanthophyllomyces dendrorhous \\
\hline Komagataella pastoris & \\
\hline
\end{tabular}

Boekhout (2003). The Yeasts. A Taxonomy Study. Kurtzman, Fell, Boekhout 2011.

\section{I YEAST CELL WALL AND POLYSACCHARIDES}

Yeast cells are surrounded by a rigid cell wall (CW) that provides physical and osmotic protection, as well as determining cell shape and integrity during cell growth and division; however, it is a dynamic structure that can adapt to physiological and morphological changes (Smith, 2000; Klis et al., 2002). This structure represents between 20 and $25 \%$ of the dry weight of the cell and consists of approximately 85 to $90 \%$ of polysaccharides and 10 to $15 \%$ of proteins (Walker, 2000).

Three different groups can be distinguished within the CW polysaccharides: on the one hand, mannose polymers or mannanoproteins that are a heterogeneous group of glycoproteins and can represent approximately $40 \%$ of the dry weight of the CW; on the other hand, the glucose polymers or $\beta$-glucan that constitute $60 \%$ of the dry weight of the $\mathrm{CW}$, and can be differentiated, according to the type of glycosidic bonds, in $\beta(1,3)$ and $\beta$ $(1,6)$ glucans, which represent $85 \%$ and $15 \%$ of these polysaccharides, respectively; and finally, the $\mathrm{N}$-acetylglucosamine polymers that make up chitin and that constitute up to $2 \%$ of the dry weight of the CW (Nguyen et al., 1998; Klis et al., 2002; Aguilar-Uscanga and François, 2003; Kath and Kulicke, 1999; Suphantharika et al., 2003). The chemical structure of carbohydrates in the CW is shown in Figure 1. 


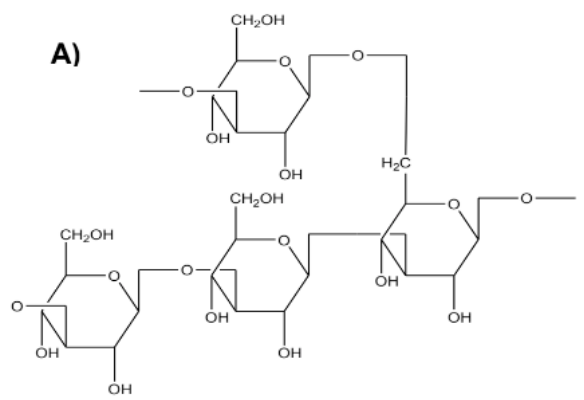

B)

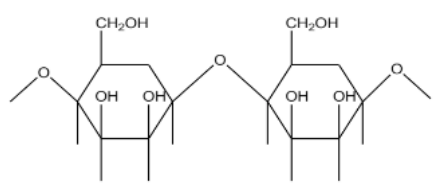

C)

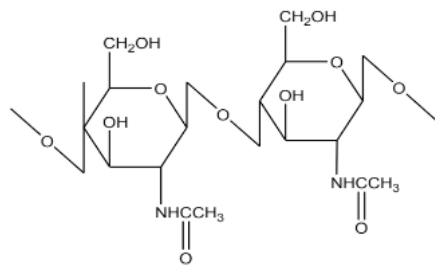

Figure 1. Chemical structure of polysaccharides from yeast cell walls. A) $\beta$ glucans, B) Mannans and C) chitin.

Cell wall polysaccharides extracted from yeast have been described as components with important biological properties in addition to their structural function, as immunomodulators (Novak and Vetvicka, 2009; Mehdi and Hasan, 2012), with antiinflammatory and antimicrobial (Vetvicka and Vetvickova 2010), antiproliferatives (Salvador et al., 2008) and antioxidants properties (Jaehrig, et al., 2007; Machová and Bystrick'y, 2013; Qiling et al., 2017). Furthermore, the physical and chemical properties of $\beta$-glucans and mannans have special interest over the years for different industrial applications (Zhu et al., 2015; Galineri et al., 2017). Studies have been carried out on the use of $\beta$ glucans from different origins in the food industry (Kittisuban et al., 2014; Lazaridou et al., 2014; Rinaldi et al., 2015), in the cosmetic industry (Vacharaprechakul et al., 2007; Kanlayavattanakul and Lourith, 2008; Medeiros et al., 2013; Du et al., 2014) and in medicine (Belcarz et al., 2013; Samuelsen et al., 2014; Levitz, 2014).

\section{I NUTRITIONAL FACTORS THAT INFLUENCE THE COMPOSITION OF THE YEAST CELL WALL}

The composition of polysaccharides, the structure and the thickness of the cell wall vary according to the different species and strains, the stage of the cell cycle and environmental conditions (Nguyen et al., 1998; Aguilar-Uscanga and François, 2003; Bähler, 2005; Smits et al., 1999; Magnelli et al., 2002) (Table 1).

Knowledge about its composition and the factors that influence it is of relevance, due to the increased commercial interest in the production of $\beta$-glucans and mannans for the different industries (Donzis, 1996; Jozef et al., 1999; Zhu et al., 2015) and, conversely, the 
need to reduce wall thickness to optimize a more effective and rapid release of endogenous biomolecules (Daran et al., 1997).

The most important factors for microbial growth are: the energy source and the carbon source and its use. The economic evaluation of the yeast production process suggests that the main contributor to the global cost is the carbon source. In recent years, different researchers have worked on obtaining $\mathrm{CW}$ and $\beta$-glucans using different carbon sources (Table 1). In biomass production, some criteria must be taken into account for the choice of the substrate. These are price, availability and abundance, toxicity, carbohydrate content and their use by microorganisms (Sharma et al., 2014).

\begin{tabular}{|c|c|c|c|}
\hline FUNGI & SPECIES & CARBON SOURCE & REFERENCE \\
\hline \multirow{5}{*}{ Yeast } & S. cerevisiae & YPD (EDTA, SDS and CINa) & Naruemon y col., 2013 \\
\hline & S. cerevisiae & YPD & Plata y col., 2013 \\
\hline & S. cerevisiae & $\begin{array}{c}\text { Mineral medio (glucose, } \\
\text { mannose, galactose, sucrose, } \\
\text { maltose, ethanol) }\end{array}$ & $\begin{array}{l}\text { Aguilar Uscanga y col. } \\
2005\end{array}$ \\
\hline & S. cerevisiae, S. boulardi & $\begin{array}{l}\text { YPD, DDGse (dried distiller } \\
\text { grains with solubles extract) }\end{array}$ & Pereyra et al., 2018 \\
\hline & $\begin{array}{l}\text { Kluyveromyces } \\
\text { marxianus }\end{array}$ & $\begin{array}{l}\text { YPD, DDGse (dried distiller } \\
\text { grains with solubles extract) }\end{array}$ & Pereyra et al., 2017 \\
\hline \multirow{3}{*}{ Mushrooms } & Pleurotus sp. & Olive mill solid waste (OMSW) & Avni et al., 2017 \\
\hline & Lentinus edodes & $\begin{array}{l}\text { Olive mill waste (OMW) and } \\
\text { phenols }\end{array}$ & Reverberi et al., 2004 \\
\hline & Lentinus edodes & $\begin{array}{l}\text { Substrates with a high content of } \\
\text { polyphenolic compounds }\end{array}$ & Ooi and Liu, 2000 \\
\hline
\end{tabular}

Table 1. Use of different carbon sources and / or additives for obtaining cell wall and $\beta$ glucans from fungi.

\section{I MATERIALS AND METHODS}

\subsection{Yeast Isolation}

Yeast strains were isolated from fifteen (15) samples of whole corn. Ten (10) grams of each sample were ground, weighed and added to $90 \mathrm{~mL}$ of sterile peptone water contained in an Erlenmeyer flask, obtaining a $10^{-1}$ dilution. Serial dilutions in sterile peptone water were made and $0.1 \mathrm{~mL}$ aliquots were inoculated in duplicate onto yeast dextrose extract (YPD) medium containing chloramphenicol ( $2 \mathrm{~mL}$ of a solution of $250 \mathrm{mg} / 100 \mathrm{~mL} 95 \%$ ethanol). The plates were incubated at $28^{\circ} \mathrm{C}$ for $24-48 \mathrm{~h}$. 


\subsection{Molecular Identification Of Yeast Strains}

\section{Yeasts culture and DNA extraction}

Yeast strains were maintained on plates containing YPD medium. Several colonies were transferred to a sterile microtube by duplicate. The pellet was frozen with liquid nitrogen for 5 min. Fungal DNA was extracted using a hexadecyltrimethylammonium bromide (CTAB 2\%) (2\% CTAB-Sigma; 1,4 M NaCl; 20 mM EDTA; 100 mM Tris-HCl 1M-pH 8) preheated to $65^{\circ} \mathrm{C}$ and $10 \mu \mathrm{L}$ of 2-mercaptoethanol (Merk) procedure following the methodology proposed by Leslie and Summerell (2006). Extraction residues were resuspended in $100 \mu \mathrm{L}$ of $1 \mathrm{X} \mathrm{TE}$ buffer $\left(10 \mathrm{mM}\right.$ Tris- $\mathrm{HCl}, 1.0 \mathrm{mM}$ EDTA, $\mathrm{pH}$ ), and stored at $-20^{\circ} \mathrm{C}$. DNA quantification was performed using a Nanodrop 2000 Spectrophotometer kit (Thermo Scientific).

\section{Obtaining profiles using PCR fingerprinting}

Microsatellite-primed PCR. The one step PCR-fingerprinting method was performed using the microsatellite primer (GTG) $)_{5}$. PCR reactions were made with 20-30 ng of fungal DNA in a total volume of $25 \mu \mathrm{L}$ of $1 \times$ reaction buffer containing $2 \mathrm{mM} \mathrm{MgCl}, 1.25 \mathrm{U} \mathrm{Taq}$ DNA polymerase (5 U. $\mu \mathrm{L}^{-1}$, Invitrogen by Life Technologies, Buenos Aires, Argentina), 0.2 $\mathrm{mM}$ of each dNTP and $0.6 \mu \mathrm{M}$ of $\mathrm{GTG}_{5}$ primer. A negative control, containing all reagents without fungal DNA, was included in every set of reactions. PCR was conducted according to the following cyclic conditions: initial denaturation at $94^{\circ} \mathrm{C}$ for $3 \mathrm{~min}$, followed by 35 cycles consisting of $94^{\circ} \mathrm{C}$ for $45 \mathrm{~s}, 54^{\circ} \mathrm{C}$ for $45 \mathrm{~s}$ and $72^{\circ} \mathrm{C}$ for $1 \mathrm{~min}$, and a final extension step of $72^{\circ} \mathrm{C}$ for $10 \mathrm{~min}$, and then held at $4^{\circ} \mathrm{C}$ indefinitely. DNA band patterns were visualized after electrophoretic run on $1.5 \%$ agarose gel stained with $0.5 \mu \mathrm{g} \cdot \mathrm{mL}^{-1}$ ethidium bromide and gels were photographed using a MiniBIS Pro, DNR Bioimaging systems analyzer. The fragment sizes were measured by comparison with DNA 100-bp ladder (Invitrogen by Life Technologies, Buenos Aires, Argentina) whose reference bands vary between 100 and 2072 bp. In addition, DNA profiles of Saccharomyces sp. and Candida sp. strains were used for comparison.

\subsection{Biomass Production Of Yeast Strains To Obtain Cell Wall}

For the biomass production, three yeast strains were selected that are beneficial according to the literature. The strains were maintained on malt extract agar (MEA).

\section{Yeast biomass production}

A concentration of $1.10^{7}$ cells. $\mathrm{mL}^{-1}(1 \mathrm{~mL})$ of yeast was inoculated into Erlenmeyertype flasks containing $100 \mathrm{~mL}$ of YPD broth at $28^{\circ} \mathrm{C}$ for $24 \mathrm{~h}$ in orbital shaker (150 rpm). At the end of the incubation time, the biomass was centrifuged at $5000 \mathrm{rpm}$ for $5 \mathrm{~min}$. The sediment was dried in a forced air oven to recover the biomass destined for extraction from the cell wall. 


\section{Influence of the addition of EDTA, SDS and CINa}

The influence of the additives was determined on: I) biomass production and the percentage of $\mathrm{CW}, \mathrm{II}$ ) the production of $\beta$ glucans, and III) and the $\beta$ glucan/chitin ratio in the $\mathrm{CW}$ of the studied strains.

YPD medium was adjusted to $\mathrm{pH} 4$ and supplemented with different concentrations of EDTA, SDS and CINa, according to Nareumon et al., 2013 (Table 2). Each medium was inoculated with $1 \mathrm{~mL}$ of a concentration of $1.10^{7}$ cells. $\mathrm{mL}^{-1}$ of yeast and incubated at $28^{\circ} \mathrm{C}$ for $24 \mathrm{~h}$ in orbital shaker (150 rpm). At the end of the incubation time, the culture media were centrifuged. The sediment (biomass) was dried in a forced air oven to recover the biomass destined for the extraction of the CW. All tests and combinations were performed in duplicate.

\begin{tabular}{cccccccc}
\hline $\begin{array}{c}\text { Additives } \\
(\mathbf{p p m})\end{array}$ & \multicolumn{7}{c}{ Treatments } \\
\cline { 2 - 8 } & $\mathrm{T} 1(\mathrm{YPD})$ & $\mathrm{T} 2$ & $\mathrm{~T} 3$ & $\mathrm{~T} 4$ & $\mathrm{~T} 5$ & $\mathrm{~T} 6$ & $\mathrm{~T} 7$ \\
\hline EDTA & 0 & 0 & 50 & 0 & 5 & 0 & 5 \\
\hline SDS & 0 & 100 & 0 & 0 & 10 & 20 & 10 \\
\hline $\mathrm{CINa}$ & 0 & 0 & 0 & 30.000 & 0 & 3000 & 3000 \\
\hline
\end{tabular}

Table 2. Concentration of additives used in YPD medium.

\section{Preparation of the yeast cell wall}

Biomass production was performed following the methodology of Nguyen et al., 1998 , with some modifications. The cultures were incubated at $28^{\circ} \mathrm{C}$ in an orbital shaker (150 rpm). Yeast cells were harvested by centrifugation at $5000 \mathrm{rpm}$ for $10 \mathrm{~min}$, washed three times with water to remove traces of culture medium and then twice more with $0.1 \mathrm{M}$ sodium phosphate buffer, $\mathrm{pH} 8.5\left(\right.$ at $4^{\circ} \mathrm{C}$ ). The biomass was dried at $60^{\circ} \mathrm{C}$ in forced air oven until constant weight.

Yeast cells were suspended in $0.1 \mathrm{M}$ sodium phosphate buffer, $\mathrm{pH} 8.5$, and an equal volume of glass beads ( $0.45 \mathrm{~mm}$ diameter). They were cooled to $4^{\circ} \mathrm{C}$ and broken by mechanical shaking for $30 \mathrm{~s}$, after which the homogenate was cooled and disrupted for another $30 \mathrm{~s}$. This procedure was repeated five times. The glass beads were removed from the homogenate by decanting, and the cell walls were separated by centrifugation at 5000 rpm for $15 \mathrm{~min}$. The cell walls were washed five times with $0.1 \mathrm{M}$ phosphate buffer, $\mathrm{pH} 8.5$, and then washed a further four times with distilled water. The temperature was kept below $4^{\circ} \mathrm{C}$ during all operations. The $\mathrm{CW}$ was dried at $60^{\circ} \mathrm{C}$ in forced air oven until constant weight.

\subsection{Study Of The Composition Of The Cell Wall}

To verify the variation in the composition of the $\mathrm{CW}$ under the influence of the 
different additives (EDTA, SDS, CINa) infrared spectroscopy (IR) was performed. The dried $\mathrm{CW}$ was mixed with $\mathrm{KCl}(1 \mathrm{mg} \mathrm{CW}$ with $200 \mathrm{mg} \mathrm{KCl}$ ). This mixture was ground in an agate mortar, finally making the tablet was performed under pressure $\left(\approx 15\right.$ ton. $\left.\mathrm{cm}^{-2}\right)$ and applying dynamic vacuum for $15 \mathrm{~min}$. Measurements were performed in a Nicolet FTIR Impact 400 spectrometer. For data acquisition and processing the software OPUS was used. The spectra were the result of an accumulation of 200 measurements, to increase signal/noise ratio, and were measured between 4000 and $400 \mathrm{~cm}^{-1}$ with a resolution of $4 \mathrm{~cm}^{-1}$.

\subsection{Statistic Analysis}

Assays were performed in duplicate for each treatment. An analysis of variance (ANOVA) was performed. When the analysis was statistically significant, the Duncan test was used to determine the importance of each individual parameter and its interactions at $\mathrm{p} \leq 0.05$. For the analysis of the data, the Info Stat program for Windows version 2015 was used.

\section{I RESULTS}

\subsection{Isolation And Identification}

Twenty-five (25) yeast strains were isolated from the 15 samples analyzed. DNA extraction and fingerprinting of all strains was performed. Two strains with the band profile of Saccharomyces sp. and one strain with the band profile similar to that obtained for Candida $\mathrm{sp}$. were selected. In a future study, the sequencing of the strains will be carried out to determine specifically what species they are.

\subsection{Biomass And Cell Wall Production}

Table 3 shows the biomass production and the CW percentage of the studied strains. The biomass production was higher in treatment 4 (with $\mathrm{CINa}$ ) for the strain Saccharomyces sp. $1(0.87 \mathrm{~g} / 100 \mathrm{~mL})$ and in treatment 5 (EDTA and SDS) for the remaining strains (0.86 g/ $100 \mathrm{~mL}$ for Saccharomyces sp. 2 and $0.79 \mathrm{~g} / 100 \mathrm{~mL}$ for Candida sp.). The average percentage of CW ranged between 10.6 and $40.3 \%$ for Saccharomyces sp. 1, from 13.3 to $36.1 \%$ for Saccharomyces sp. 2, and from 27.4 to $40.5 \%$ for Candida sp. For Saccharomyces sp. 1 , the percentage of CW was higher (40.3 - 39.1\%) when it was grown only in YPD medium (T1) and in YPD with the 3 additives (T7). For Saccharomyces sp. 2 it was observed that in the T6 treatment (SDS - CINa) it achieved the highest percentage of CW (36.1\%) and for Candida sp. the highest percentage of CW was when it was grown in YPD medium with EDTA and SDS (T5). 
Strains

\begin{tabular}{ccccccc}
\cline { 2 - 7 } Treatments & \multicolumn{2}{c}{ Saccharomyces sp. 1 } & \multicolumn{2}{c}{ Saccharomyces sp. 2 } & \multicolumn{2}{c}{ Candidasp. } \\
\cline { 2 - 7 } & $\begin{array}{c}\text { Biomass } \\
\text { production } \\
(\mathrm{g} / 100 \mathrm{~mL})\end{array}$ & $\begin{array}{c}\mathrm{CW} \\
\text { percentage } \\
(\%)\end{array}$ & $\begin{array}{c}\text { Biomass } \\
\text { production } \\
(\mathrm{g} / 100 \mathrm{~mL})\end{array}$ & $\begin{array}{c}\mathrm{CW} \\
\text { percentage } \\
(\%)\end{array}$ & $\begin{array}{c}\text { Biomass } \\
\text { production } \\
(\mathrm{g} / 100 \mathrm{~mL})\end{array}$ & $\begin{array}{c}\text { CW } \\
\text { percentage } \\
(\%)\end{array}$ \\
\hline $\mathrm{T} 1$ & 0.67 & 40.3 & 0.69 & 32.8 & 0.75 & 36.0 \\
\hline T2 & 0.62 & 10.6 & 0.58 & 13.3 & 0.62 & 27.4 \\
\hline T3 & 0.69 & 34.8 & 0.62 & 29.0 & 0.68 & 30.9 \\
\hline T4 & 0.86 & 25.6 & 0.73 & 30.1 & 0.68 & 33.8 \\
\hline T5 & 0.75 & 36.0 & 0.86 & 31.4 & 0.79 & 40.5 \\
\hline T6 & 0.61 & 26.2 & 0.72 & 36.1 & 0.74 & 33.8 \\
\hline T7 & 0.68 & 39.1 & 0.54 & 29.6 & 0.75 & 32.8 \\
\hline
\end{tabular}

Table 3. Biomass production and cell wall (CW) percentage of Saccharomyces sp. 1, Saccharomyces sp. 2 and Candida sp. obtained from the different treatments.

T1: Control (YPD), T2: SDS, T3: EDTA T4: CINa, T5: EDTA - SDS, T6: SDS - CINa, T7: EDTA - SDS - CINa.

The correlation between the amount of biomass $(\mathrm{g} / 100 \mathrm{~mL})$ and the amount of CW $(\mathrm{g} /$ $100 \mathrm{~mL}$ ) was determined for the 3 studied strains (Figure 2). For the strain Saccharomyces sp. 1 there was no correlation between both parameters. For the Saccharomyces sp. 2 and Candida sp. a positive correlation was observed between cell concentration and WC content, with values of $R=0.83$ and $R=0.94$, respectively.
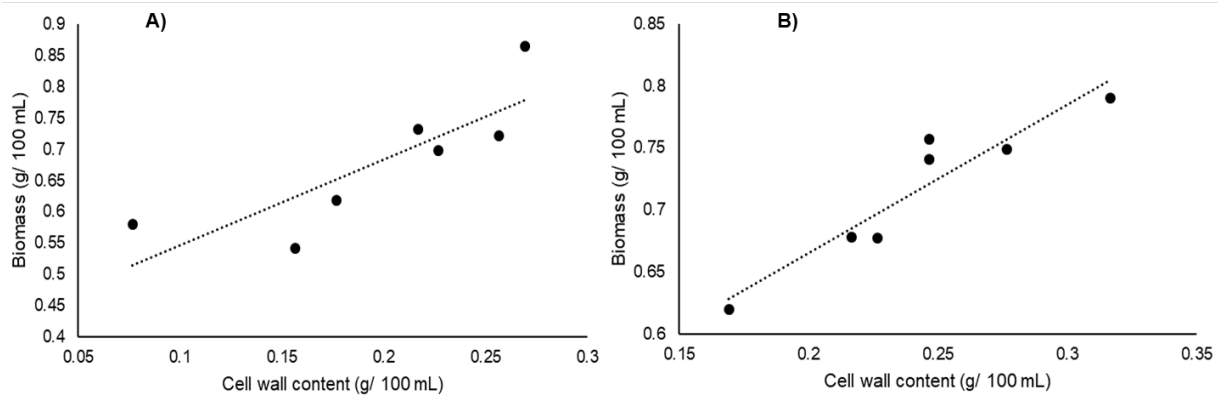

Figure 2. Correlation between cell wall content and amount of biomass. A) Saccharomyces sp. 2, B) Candida sp.

\subsection{Study Of The Composition Of The Cell Wall}

To verify the variation in the composition of the $\mathrm{CW}$ under the influence of different carbon sources, infrared (IR) spectroscopy was performed. The spectra of each CW in the 7 studied treatments show three regions corresponding to carbohydrates $\left(950-1185 \mathrm{~cm}^{-}\right.$ 
$\left.{ }^{1}\right)$, proteins $\left(1480-1700 \mathrm{~cm}^{-1}\right)$ and lipids $\left(2840-3,000 \mathrm{~cm}^{-1}\right)$. In the carbohydrate region, the $\beta$-glucans are observed and, in the protein region, the chitin is shown, represented by the bands amide I and amide II (Figures 3, 4 and 5). The 3 strains behaved differently in the 7 studied treatments. In addition to determine the presence of glucans and chitin, a semi quantitative comparison of the main infrared bands present in the 7 treatments for each strain was carried out to determine which of the additives present in the culture medium enhances the $\beta$-glucans production. Figure 3 shows the infrared spectrum of the $\mathrm{CW}$ of the Saccharomyces sp. 1 strain where it showed a higher amount of carbohydrates (region between 1400 and $800 \mathrm{~cm}^{-1}$ ) when it was cultivated in YPD medium with SDS (T2), in that treatment it is observed that the $\beta$ glucans/chitin ratio is greater than 1 . The combination of the three additives (EDTA, SDS, $\mathrm{NaCl}$ ) in the culture medium (T7) also enhanced the production of $\beta$-glucans. Figure 4 shows the infrared spectrum of the $\mathrm{CW}$ of the Saccharomyces sp. 2 strain. The T5 treatment (EDTA, SDS) was theoretically the best for obtaining carbohydrates, however, the $\beta$ glucan/chitin ratio is of 1 . By contrast, the treatment T2 (SDS) shows that the relation $\beta$ glucans/chitin is greater than 1 . The infrared spectrum of the CW of the Candida sp. strain is shown in figure 5 . Treatments 1 and 2 are similar in terms of the influence on the production of $\beta$ glucans. The $\beta$ glucans/chitin relationship is 1 for all treatments, including T1 and T2.

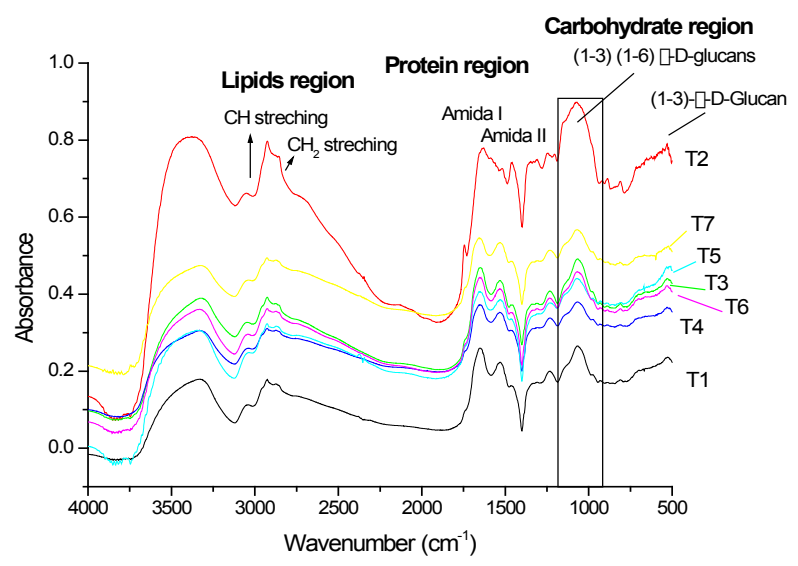

Figure 3. FITR spectra of Saccharomyces sp. 1 cell wall grown in different treatments. T1: Control (YPD), T2: SDS, T3: EDTA T4: CINa, T5: EDTA - SDS, T6: SDS - CINa, T7: EDTA SDS - CINa. 


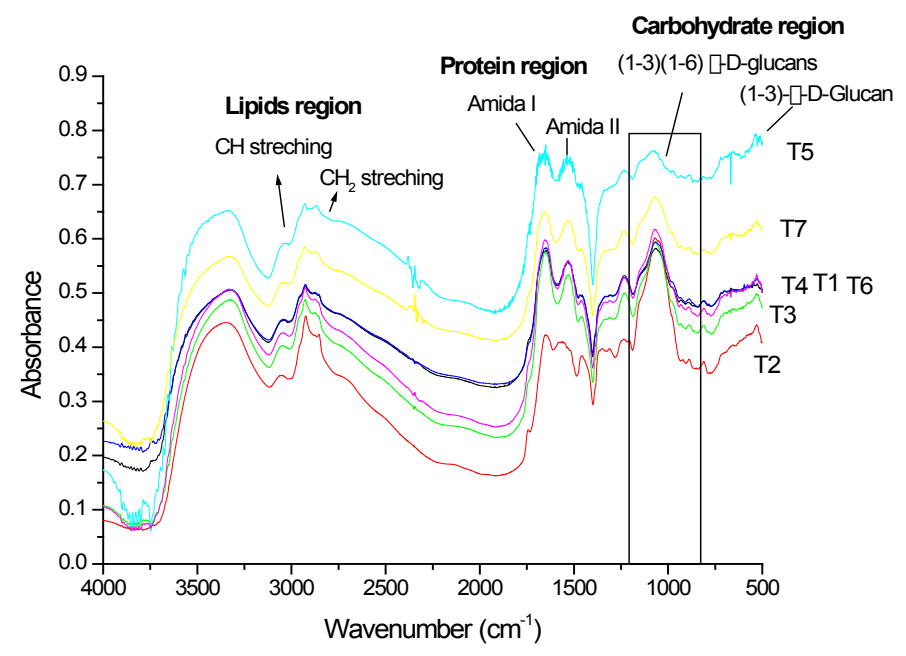

Figure 4. FITR spectra of Saccharomyces sp. 2 cell wall grown in different treatments. T1: Control (YPD), T2: SDS, T3: EDTA T4: CINa, T5: EDTA - SDS, T6: SDS - CINa, T7: EDTA SDS - CINa.

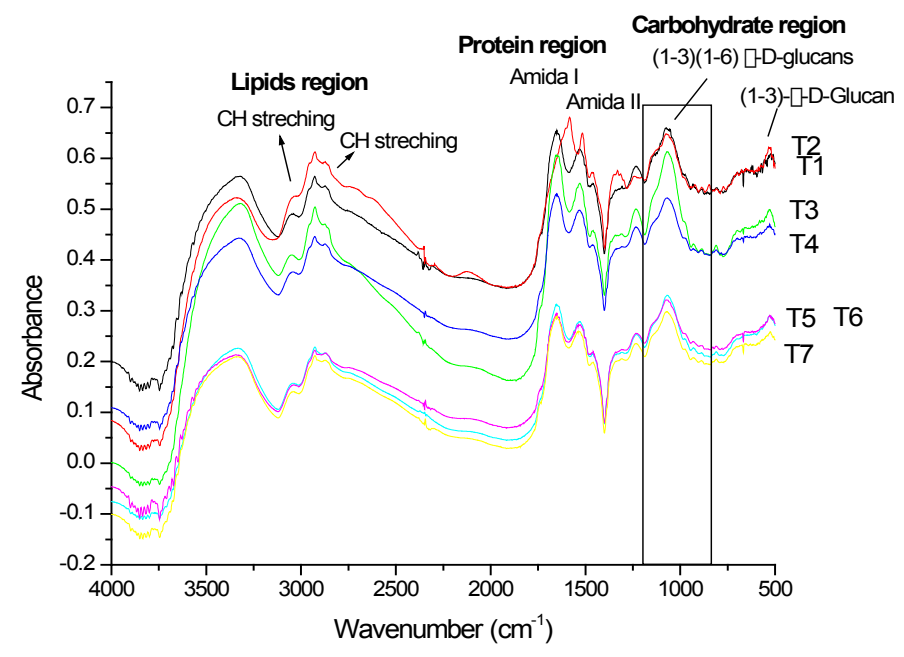

Figure 5. FITR spectra of Candida sp. cell wall grown in different treatments. T1: Control (YPD), T2: SDS, T3: EDTA T4: CINa, T5: EDTA - SDS, T6: SDS - CINa, T7: EDTA - SDS - CINa. 


\section{I DISCUSION}

This study evaluated the incorporation of 3 additives (EDTA, SDS and CINa) to a culture medium such as YPD, to determine the influence on biomass production and cell wall content of Saccharomyces sp. 1; Saccharomyces sp. 2 and Candida sp. strains to be used in the future as producers of $\beta$-glucans.

The biomass concentration of the 3 studied strains in the 7 treatments was higher than those found by Serrat Díaz et al., (2017), they studied the influence of the carbon source, nitrogen source and temperature, where the average concentration ranged from 0.089 to $0.465(\mathrm{~g} / 100 \mathrm{~mL})$. Dhanasekaran et al., (2011) studied the production of yeast biomass using pineapple residue, where a dry biomass content of $0.572(\mathrm{~g} / 100 \mathrm{~mL})$ for S. cerevisiae and $0.492(\mathrm{~g} / 100 \mathrm{~mL})$ for $C$. tropicalis was observed. Pereyra et al., (2018) studied the use of YPD medium and dried distiller grains with soluble extract (DDGse) for the biomass production of 3 probiotic strains (2 strains of $S$. cerevisiae and $S$. boulardii). These authors demonstrated a production between 0.405 to $0.5(\mathrm{~g} / 100 \mathrm{~mL})$ in YPD and from 0.315 to $0.402(\mathrm{~g} / 100 \mathrm{~mL})$ in DDGse. In this study the biomass production was used for the extraction of $\mathrm{CW}$ and to determine the content of $\beta$-glucans.

In general, the CW of Saccharomyces cerevisiae, is about $70 \mathrm{~nm}$ thickness that represent $20 \%$ of the whole cell's weight (Walker, 1999). The CW values found in this work varied between 10.6 to $40.3 \%$ (Saccharomyces sp. 1), from 13.3 to $36.1 \%$ (Saccharomyces sp. 2) and from 27.4 to $40.5 \%$ (Candida sp.). The average contents of CW were mostly within the range usually reported for yeast (Lipke and Ovalle, 1998). The composition of the $\mathrm{CW}$ can vary under different growth conditions, including the type of culture, carbon source, temperature, $\mathrm{pH}$, and aeration (Aguilar-Uscanga and François, 2003; Naruemon et al., 2013). Aguilar Uscanga et al., (2005) studied the variation of polysaccharides composition present in the $\mathrm{CW}$ of $S$. cerevisiae using different carbon sources (glucose, mannose, galactose, sucrose, maltose, and ethanol) and found that the percentage of CW in dry weight was $10 \%$ for the culture made with $25 \%$ ethanol in the sucrose culture. Serrat Díaz et al., (2017) obtained CW percentages of Kluyveromyces marxianus from 12.3 to $27.6 \%$ when it was grown on different carbon sources (glucose, sucrose and lactose), different sources of nitrogens (peptone and $\left.\left(\mathrm{NH}_{4}\right)_{2} \mathrm{SO}_{4}\right)$ ), different temperatures $\left(30\right.$ and $40{ }^{\circ} \mathrm{C}$ ), $\mathrm{pH}$ (3.4 and 5.4) and in aerobiosis and microarobiosis. Nguyen et al., (1998) considered that it is important to maximize the performance of cell walls to minimize economic costs, if used commercially.

In this work, the composition of the extracted CW using FTIR was studied. The FTIR spectroscopy can be applied as a useful tool for the analysis of entire yeast cells providing a fast, effective, reagent-free, and simple method (Kuligowski et al., 2012). The FTIR spectroscopy is a rapid, precise, and accurate method, not requiring sample preparation, for the determination and quantification of carbohydrate composition of yeast (Novák and 
Vetvi, 2009; Novák et al., 2012; Plata et al., 2013). The functional groups present on the cell surface can be identified by FTIR spectroscopy because each group has a unique energy absorption band (Jin and Bai, 2002). With this technique it was possible to study the carbohydrate variation of the CW under the influence of different additives.

The glucans content, and the $\beta$-glucan/ chitin ratio in particular, varied with the yeast strain and with the additive studied, suggesting that these species could potentially be sources of these polysaccharides. These considerations of the influence of growth parameters are important if the goal is to maximize CW yields, as would be the case in commercial situations. Furthermore, more studies are required on the chemical and physical properties of these polysaccharides to determine their structure and evaluate their industrial or medical applications. On the other hand, it is necessary to take into account the form of extraction of $\beta$-glucans and the different methods of determining the concentration in the CW.

\section{I CONCLUSION}

This study determined the influence of additives on yeast CW and biomass production. The 7 treatments were optimal for biomass production. The YPD medium (control) and the YPD with the 3 additives favored the percentage of CW for the Saccharomyces sp. 1 strain. For the Saccharomyces sp. 2 the optimal medium for the production of CW was YPD with SDS and CINa, while for the Candida sp. strain it was the medium with EDTA and SDS.

The IR study of the 3 strains shows that the composition of $\mathrm{CW}$ contains chemical groups related to $\beta$-glucans. Future studies must be done to extract the $\beta$-glucans and determine their concentration in each CW.

The optimization of the production of $\mathrm{CW}$ and its components from yeast strains will allow its application in obtaining $\beta$-glucans for the food, pharmacological and cosmetic industries.

\section{ACKNOWLEDGEMENTS}

The author is grateful to the Universidad Nacional de Rio Cuarto, Consejo Nacional de Investigaciones Científicas y Técnicas, Argentina (CONICET), Agencia Nacional de Promoción Científica y Tecnológica (ANPCYT-FONCYT) which supported this study through grants. 


\section{REFERENCE}

AGUILAR USCANGA B, and FRANÇOIS J.M. 2003. A study of the yeast cell wall composition and structure in response to growth conditions and mode of cultivation. Letters in Applied Microbiology, 37(3), 268-274.

AGUILAR USCANGA B, SOLIS PACHECO J, and FRANÇOIS J. 2005. Estudio de la variación de la composición de los polisacáridos contenidos en la pared celular de la levadura Saccharomyces cerevisiae. e-Gnosis, 3, 0 núm.

AVNI S, EZOVE N, HANANI H, YADID I, KARPOVSKY M, HAYBY H, GOVER O, HADAR Y, SCHWARTZ B, DANAY O. 2017. Olive Mill Waste Enhances a-Glucan Content in the Edible Mushroom Pleurotus eryngii. International Journal of Molecular Sciences 18(7):1564.

BÄHLER J. 2005. Cell-cycle control of gene expression in budding and fission yeast. Annual Review of Genetics, 39, 69-94.

BELCARZ A, GINALSKA G, PYCKA T, ZIMA A, ŚLÓSARCZYK A, POLKOWSKA I, PASZKIEWICZ $Z$, PIEKARCZYK W. 2013. Application of $\beta$-1,3-glucan in production of ceramics-based elastic composite for bone repair. Open Life Sci. 8, 534-548.

DARAN J.M, BELL W, and FRANÇOIS J. 1997. Physiological and morphological effects of genetic alterations leading to a reduced synthesis of UDP-glucose in Saccharomyces cerevisiae. FEMS Microbiology Letters, 153, 89-96.

DEAK T. 2009. Ecology and biodiversity of yeasts with potential value in biotechnology. En: T. SATYANARAYANA and G. KUNZE (eds.), Yeast Biotecnology: Diversity and Application. Springer Science-Business Media B.V.

DHANASEKARAN D, LAWANYA S, SAHA S, THAJUDDIN N, PANNEERSELVAM A. 2011. Production of single cell protein from pineapple waste using yeast. Innovative Romanian Food Biotechnology. (2011) 8, 26-32.

DONZIS B.A. 1996. Substantially purified beta $(1,3)$ finely ground yeast cell wall glucan composition with dermatological and nutritional uses. US patent 5576015.

DU B, BIAN Z.X, AND XU B.J. 2014. Skin health promotion effects of natural betaglucan derived from cereals and microorganisms: a review. Phytotherapy Research, 28, 159-166.

FRANCOIS J.M. 2006. A simple method for quantitative determination of polisaccharides in fungal cell walls. Nature Protocols, 1 (6).

GALINARI E, ARAÚJO SABRY D, LANZI SASSAKI G, RIBEIRO MACEDO G, LOPES PASSOS F.M, CUQUETTO MANTOVANI H, OLIVEIRA ROCHA H.A. 2017. Chemical structure, antiproliferative and antioxidant activities of a cell wall_-d-mannan from yeast Kluyveromyces marxianus. Carbohydrate Polymers 157, 1298-1305.

JAEHRIG S.C, ROHN S, KROH L.W, FLEISCHER L.G, and KURZ T. 2007. In vitro potential antioxidant activity of (1口3), (1口6)- $\beta$-d-glucan and protein fractions from Saccharomyces cerevisiae cell walls. Journal of Agricultural and Food Chemistry, 55, 4710-4716. 
JOHNSON E.A, and ECHAVARRI ERASUN C. 2011. The Yeast, a Taxonomy Study, Chapter 3. Yeast Biotechnology.

JOHNSON E.A. 2013. Biotechnology of non-Saccharomyces yeasts-the ascomycetes. Appl. Microbiol. Biotechnol., 97, 503-517.

JOZEF S, KOGAN G, KACUROKOVA M, and MACHOVA E. 1999. Microbial (1,3)-b-D-glucans, their preparation, physico-chemical characterization and immunomodulatory activity. Carbohydrate Polymers, 38, 247-253.

KANLAYAVATTANAKUL M, and LOURITH N. 2008. Carboxymethylglucan in cosmetics. Thai Pharmaceutical and Health Science Journal, 3, 378-382.

KATH F, and KULICKE W.M. 1999. Mild enzymatic isolation of mannan and glucan from yeast Saccharomyces cerevisiae. Die Angewande Macromoleculare Chemie, 268, 59-68.

KITTISUBAN P, RITTHIRUANGDEJ P, and SUPHANTHARIKA M. 2014. Optimization of hydroxypropylmethylcellulose, yeast b-glucan, and whey protein levels based on physical properties of gluten-free rice bread using response surface methodology. LWT Food Science and Technology, 57, 738-748.

KLIS F, MOL P, HELLINGWERF K, and BRUL S. 2002. Dynamic of cell wall structure in Saccharomyces cerevisiae. FEMS Microbiology Reviews, 26, 239-256.

KULIGOWSKI J, QUINTÁS G, HERWIG C, and LENDL B. 2012. A rapid method for the differentiation of yeast cells grown under carbon and nitrogen-limited conditions by means of partial least squares discriminant analysis employing infrared micro-spectroscopic data of entire yeast cells. Talanta.

KURTZMAN P.C, FELL J.W, BOEKHOUT T. (eds.). 2011. The Yeasts, a Taxonomic Study 2011, 5th Edition, Elsevier B.V

KWIATKOWSKI S, and KWIATKOWSKI S.E. 2012. Yeast (Saccharomyces cerevisiae) Glucan Polysaccharides - Occurrence, Separation and Application in Food, Feed and Health Industries. Chapter 2.

LAZARIDOU A, BILIADERIS C, MICHA-SCRETTAS M, STEELE B. 2004. A comparative study on structure-function relations of mixed-linkage (1口3), (1口4) linear $\beta$-D-glucans. Food Hydrocoll. 18 , 837-855.

LESLIE J, SUMMERELL B. 2006. The Fusarium laboratory manual, First edit. ed. Blackwell Publishing

LEVITZ S. 2014. $\beta$-Glucan particles as a vaccine platform with intrinsic adjuvanticity (469.3). FASEB Journal, 28, 469-473

LIPKE P.N, OVALLE R. 1998. Cell wall architecture in yeast: New structure and new challenges. J. Bacteriol., 180, 3735-3740. 
MACHOVÁ E, and BYSTRICK'Y S. 2013. Antioxidant capacities of mannans and glucans are related to their susceptibility of free radical degradation. International Journal of Biological Macromolecules, 61, 308-311.

MAGNELLI P, CIPOLLO J.F, and ABEIJON C. 2002. A refined method for the determination of Saccharomyces cerevisiae cell wall composition and b-1,6-glucan fine structure. Analytical Biochemistry, 301, 136-150.

MANUEL SERRAT-DÍAZ, JUAN A. VALLEJO-VIDAL, JOSÉ M. AGEITOS-MARTÍNEZ, GABRIEL LAURADÓ-MAURI, IMILCI URDANETA-LAFFITA, TOMÁS G. VILLA. 2017. Influence of the Culture Conditions on the Growth and Cell Wall Content in a Flocculent Strain of Kluyveromyces marxianus. Rev. Cubana Quím. Vol. 29, no.1, págs. 89-102, e-ISSN: 2224-5421.

MEDEIROS S.D.V, CORDEIRO S.L, CAVALCANTI J.E, MELCHUNA K.M, LIMA A.M, FILHO I.A., et al. 2013. Effects of purified Saccharomyces cerevisiae (1/3)-bglucan on Vevnous ulcer healing. International Journal of Molecular Sciences, 13, 8142-8158.

MEHDI, A., and HASAN, G. 2012. Immune response of broiler chicks fed yeast derived mannan oligosaccharides and humate against Newcastle disease. World Applied Sciences Journal, 18, 779-785.

NARUEMON M, ROMANEE S, CHEUNJIT P, XIAO H.M.C, LANDSBOROUGH L.A, and PAWADEE M. 2013. Influence of additives on Saccharomyces cerevisiae $\beta$-glucan production. International Food Research Journal, 20(4), 1953-1959.

NGUYEN T.H, FLEET G.H, and ROGERS P.L. 1998. Composition of the cell walls of several yeast species. Applied Microbiology Biotechnology, 50, 206-212.

NOVÁK M, SYNYTSYA A, GEDEON O, SLEPICKA P, PROCHÁZKA V, SYNYTSYA A, BLAHOVEC J, HEJLOVÁ A, COPÍKOVÁ J. 2012. Yeast (1-3),(1-6)-d-glucan films: Preparation and characterization of some structural and physical properties. Carbohydrate Polymers 87, 2496-2504.

NOVÁK M, and VETVICKA V. 2009. Glucans as biological response modifiers. Endocrine, Metabolic and Immune Disorders - Drug Targets, 9, 67-75.

OCDE, Organización para la Cooperación y el Desarrollo Económico. 2005. A Framework for Biotechnology Statistics, OECD, París.

OOI VEC, LIU F. 2000. Immunomodulation and anti-cancer activity of polysaccharide - protein complexes. Curr Med Chem. 7:715-729.

PEREYRA C, GIL S, MAKITA M, CRISTOFOLINI A, MONGE M, BAINOTTI B, et al. 2017. Potencial Biotecnológico de Kluyveromyces marxianus VM004 Para Adsorber Aflatoxina B1. IX Congreso Latinoamericano de Micología. Agosto de 2017. Lima, Perú.

PEREYRA CM, GIL S, CRISTOFOLINI A, BONCI M, MAKITA M, MONGE MP, et al. 2018. The production of yeast cell wall using an agroindustrial waste influences the wall thickness and is implicated on the aflatoxin $\mathbf{B}_{1}$ adsorption process. Food Research International 111, 306-313. 
PLATA M.R, KOCH C, WECHSELBERGER P, HERWIG C, and LENDL B. 2013. Determination of carbohydrates present in Saccharomyces cerevisiae using mid-infrared spectroscopy and partial least squares regression. Analytical and Bioanalytical Chemistry, 405(25), 8241-8250.

REVERBERI M, DI MARIO F, and TOMATI U. 2004. $\beta$-Glucan synthase induction in mushrooms grown on olive mill wastewaters. Appl Microbiol Biotechnol., 66: 217-225. DOI 10.1007/s00253-0041662-y.

RINALDI L, RIOUX L.E, BRITTEN M, TURGEON S.L. 2015. In vitro bioaccessibility of peptides and amino acids from yogurt made with starch, pectin, or $\beta$-glucan. Int. Dairy J. 46, 39-45.

ROMANO P, CAPECE A, JESPERSEN L. 2006. Taxonomic and Ecological Diversity of Food and Beverage Yeasts. Chapter 2. The Yeast Handbook. Amparo Querol, Graham H. Fleet (Eds.): Yeasts in Food and Beverages. (C) Springer-Verlag Berlin Heidelberg.

SALVADOR C, LI B, HANSEN R, CRAMER D.E, KONG M, and JUN Y. 2008. Yeast-derived $\beta$-glucan augments the therapeutic efficacy mediated byanti?vascular endothelial growth factor monoclonal antibody in human carcinoma xenograft models. Clinical Cancer Research, 14, $1239-1247$.

SAMUELSEN A.B, SCHREZENMEIR J, and KNUTSEN S.H. 2014. Effects of orally administered yeast-derived beta-glucans: a review. Molecular Nutrition \& Food Research, 58, 183-193.

SHARMA N.K, BENIWAL V, KUMAR N, KUMAR S, PATHERA A.K, and RAY A. 2014. Production of tannase under solid-state fermentation and its application in detannification of guava juice. Preparative Biochemistry and Biotechnology, 4(3), 281-290.

SMITH A.E, ZHANG Z, THOMAS C.R, MOXHAM K.E, and MIDDELBERG A.P. 2000. The mechanical properties of Saccharomyces cerevisiae. Proceedings of the National Academy of Sciences, USA, 97, 9871-9874.

SMITS G.J, KAPTEYN J.C, VAN DEN ENDE H, and KLIS F.M. 1999. Cell wall dynamics in yeast. Current Opinion in Microbiology, 2(4), 348-352.

SUPHANTHARIKA M, KHUNRAE P, THANARDKIT P, and VERDUYN C. 2003. Preparation of spent brewer's yeast $\beta$-glucans with a potential application as an immunostimulant for black tiger shrimp, Penaeus monodon. Bioresource Technology, 88(1), 55-60.

VACHARAPRECHAKUL V, KRISDAPHONG P, and KANLAYAVATTANAKUL M. 2007. The development and clinical evaluation of carboxymethyl glucan. M. Sc. (Cosmetic Science) Independence Study. Chiang Rai: Mae Fah Luang University.

WALKER G.M. 2000. Yeast physiology and biotechnology. Wiley, Chichester.

ZHU F, DU B, and XU B. 2015. A critical review on production and industrial applications of betaglucans. Food Hydrocolloids, 52, 275-288.

ŻYMAŃCZYK-DUDA E, BRZEZIŃSKA-RODAK M, KLIMEK-OCHAB M, DUDA M, and ZERKA A. 2017. Yeast as a Versatile Tool in Biotechnology. DOI: 10.5772/intechopen.70130. 


\section{ÍNDICE REMISSIVO}

B-glucans 140, 143, 144, 149, 151, 152, 156

\section{A}

Ácido Acetilsalicílico 13, 157, 158, 159

Additives 140, 144, 146, 147, 149, 151, 152, 155

Adsorção 157, 158, 159, 160, 163, 167, 168, 169, 172

Aeromonadaceae $43,44,48,50$

Amilase 65, 66, 68, 70, 72, 73, 95, 98, 99, 100, 101

Aplicações industriais 66, 68, 70, 78, 79, 97, 106, 132, 138

Aspectos Microbiológicos 9, 176

Aspergillus tamarii 12, 118, 119, 121, 122, 123, 124, 125, 126, 127, 130, 131, 133, 134, 135, 136, 137, 138

\section{B}

Biodegradação 157, 158, 159, 160, 163, 165, 166, 168, 169, 172

Biofilme 13, 58, 157, 158, 160, 161, 162, 163, 164, 168, 169, 171, 172

Bioprospecção 65, 66, 75, 138

\section{C}

Cell Wall 12, 140, 142, 143, 144, 145, 146, 147, 148, 149, 150, 151, 153, 154, 155

Celulase 95, 98, 99, 100, 102, 107, 133

Contaminação microbiana 2, 63

Contamination $10,2,16,17,43,44,45,50,51,52,64,86$

\section{D}

Dengue 10, 38, 39, 40, 41, 42

Design de Plackett-Burman 109, 110, 111, 112, 113, 114, 115

Diagnóstico 10, 14, 16, 17, 18, 21, 22, 36, 178, 179, 180

Diversidade Microbiana 158, 171, 172

Drenagem Urbana 2

E

Enterobacteriaceae 44, 48, 50, 57

Enzima fibrinolítica 119, 126

Epidemiologia 34, 38, 42, 63

Escarro 10, 14, 16, 18, 19, 20, 21, 22

Esgoto $1,2,3,7,159,161,172$ 
Extração 30, 33, 68, 119, 121, 126, 134, 140, 161

$\mathbf{F}$

Farelo de soja 109, 110, 111, 112, 113, 114, 115

Fermentação 91, 97, 108, 110, 119, 121, 131, 138

Fermentação Submersa 72, 95, 97, 98, 99, 106, 107, 109, 110, 111, 116, 131, 132, 133, 134, 135, 136, 138

Fitoterápicos 23

Floresta Atlântica 23

Fungo endofítico 12, 109, 110, 111

Fungo Filamentoso 102, 131, 134, 157, 164, 166, 171

Fungos $9,11,4,18,20,23,25,27,54,64,65,66,67,68,70,71,72,74,75,95,97,98$, $99,100,102,103,104,105,106,107,108,109,110,111,112,120,131,132,136,137$, 138, 160, 182

\section{H}

Hidrolase 131

I

Infecção Hospitalar 55, 61, 63, 64

$\mathbf{L}$

Linhagens de Levedura 79

Lipase 68, 75, 95, 96, 98, 99, 100, 101, 104, 137

M

Mollusks 43, 44, 45

Mycobacterium tuberculosis 13, 14, 15, 17, 176, 177

0

Óleos essenciais $36,78,79$

$\mathbf{P}$

Pau d'alho 23

Pectinase 65, 66, 72

Protease $68,75,95,96,98,99,100,104,105,106,108,122,124,127,128,129,131,132$, $134,136,137,138,139$

Q

Quitinase 12, 109, 110,111, 112, 113, 114, 115, 116 
$\mathbf{R}$

Resíduos Agroindustriais 12, 104, 130, 131, 133, 135, 138

Resistência microbiana 55, 59

S

Saccharomyces Sensu Stricto 78, 79, 81, 83, 85, 86, 90, 91, 93

Sensibilidade 10, 14, 18, 23

Sistema bifásico 119

Sobral 10, 13, 14, 38, 39, 40, 41, 176, 177, 178, 180, 181

Superfícies contaminadas 55

T

Tuberculose $10,13,14,15,16,17,18,21,22,176,177,178,179,180,181$

V

Vibrionaceae $43,44,48,50$

Y

Yeast 12, 33, 78, 79, 81, 82, 83, 84, 85, 86, 87, 88, 89, 90, 91, 92, 93, 140, 141, 142, 143, $144,145,146,147,151,152,153,154,155,156$ 


\section{PROJETOS INOVADORES E}

\section{PRODUÇÃO INTELECTUAL}

NA MICROBIOLOCIA

www.atenaeditora.com.br contato@atenaeditora.com.br $\ltimes$

@atenaeditora 우

www.facebook.com/atenaeditora.com.br ff

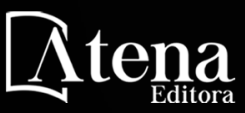

Ano 2020 


\section{PROJETOS INOVADORES E}

\section{PRODUÇÃO INTELECTUAL}

NA MICROBIOLOCIA

www.atenaeditora.com.br contato@atenaeditora.com.br $\measuredangle$

@atenaeditora 우

www.facebook.com/atenaeditora.com.br ff

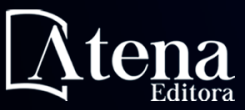

Ano 2020 